IZA DP No. 5257

Determinants of Employer-Provided Further Training: A Multi-Level Approach

Lutz Bellmann

Christian Hohendanner

Reinhard Hujer

October 2010 


\title{
Determinants of Employer-Provided Further Training: A Multi-Level Approach
}

\author{
Lutz Bellmann \\ Friedrich-Alexander University of Erlangen-Nuremberg, \\ IAB Nuremberg and IZA
}

\section{Christian Hohendanner}

IAB Nuremberg

Reinhard Hujer

Goethe University of Frankfurt, ZEW Mannheim and IZA

\section{Discussion Paper No. 5257 \\ October 2010}

\author{
IZA \\ P.O. Box 7240 \\ 53072 Bonn \\ Germany \\ Phone: +49-228-3894-0 \\ Fax: +49-228-3894-180 \\ E-mail: iza@iza.org
}

Any opinions expressed here are those of the author(s) and not those of IZA. Research published in this series may include views on policy, but the institute itself takes no institutional policy positions.

The Institute for the Study of Labor (IZA) in Bonn is a local and virtual international research center and a place of communication between science, politics and business. IZA is an independent nonprofit organization supported by Deutsche Post Foundation. The center is associated with the University of Bonn and offers a stimulating research environment through its international network, workshops and conferences, data service, project support, research visits and doctoral program. IZA engages in (i) original and internationally competitive research in all fields of labor economics, (ii) development of policy concepts, and (iii) dissemination of research results and concepts to the interested public.

IZA Discussion Papers often represent preliminary work and are circulated to encourage discussion. Citation of such a paper should account for its provisional character. A revised version may be available directly from the author. 
IZA Discussion Paper No. 5257

October 2010

\section{ABSTRACT \\ Determinants of Employer-Provided Further Training: A Multi-Level Approach}

We analyse the influence of regional determinants on the decision of employers to provide within-firm further training. We estimate the effects of the regional population density, the unemployment rate and the regional concentration of an industry against the background of several determinants of further training at the establishment level. To account for the clustered and longitudinal structure of our data - with annual observations of firms and firms nested within regions - we apply multi-level random effects logit models. Our empirical analysis is based on the IAB-Establishment Panel 2001 to 2007.

JEL Classification: J24, I21, C33, R12

Keywords: multi-level panel analysis, human capital, further training, regional labour markets

Corresponding author:

Lutz Bellmann

Institute for Employment Research (IAB)

Regensburger Strasse 104

D-90478 Nuremberg

Germany

E-mail: lutz.bellmann@iab.de 


\section{Introduction}

In the light of the Lisbon strategy, which aims at making of Europe the most competitive and productive region of the world, the number of establishments financing a further training course or releasing employees for participation in measures is of particular interest, because of the productivity gains associated with the formation of human capital (Bassanini et al., 2005). However, certain groups of employees as older persons, single mothers and migrants as well as small and medium sized companies participate less than the large ones in continuing training. In regions with a relatively high unemployment rate the participation of firms in further training seems to be lower due to the availability of qualified workers from the unemployment stock, whereas with regard to the regional population density the positive effect of the physical proximity of employees and firms is reduced by the negative effects caused by higher wages, more turnover and also more poaching. Thus the effect of regional population density remains unclear from a theoretical point of view.

In this paper, we assess the effect of both the regional population density, the unemployment rate and the regional concentration of industry against the background of several determinants of further training at the establishment level. Previous studies include Brunello and De Paola (2008) and Brunello and Gambarotto (2007) for Italy and the U.K.. These studies find a negative correlation between economically denser regions and further training. However, the institutional background and the proportion of establishments financing a further training course or releasing employees for participation in measure are quite different in Germany (Brunello / De Paola, 2008, 128). The only study for Germany by Bellmann and Leber (2005) finds a positive correlation between population density and further training. The study is based on an analysis of the IAB-Establishment Panel 2001 and 2003. In our study we use the same data and extend the observation period from 2001 to 2007.

From a methodological point of view multi-level approaches are adequate allowing the separation of the effects at the establishment and the regional level. To our best knowledge, there is no earlier study in which a multi-level and panel econometric approach is used to investigate the regional effects on employer-provided further training. Since the number of establishments interviewed in our survey is well above 15,000 each year, the regional variation within approximately 150 labour market regions is quite large.

The paper is organized as follows: In Section 2 we discuss the hypotheses and related research studies, especially the previous empirical analyses pertaining to the regional unemployment and population density on employer-provided further training. In Section 3 we 
specify the econometric model and describe the data basis. Section 4 presents the empirical results and section 5 contains a summary and research perspective.

\section{Theoretical Approach and Related Research Studies}

As a starting point to explain establishment-level training activities it is useful to refer to the human capital theory (Becker, 1964). A decisive element of this theoretical approach is the distinction between specific and general human capital. Whereas the employer and his employees share both the costs and returns of specific training, in the case of complete competition it is not worthwhile for firms to invest in general or transferable human capital because they have no guarantee that employees who have received general training will remain in the firm once they have completed their training. If the trainees leave, the firm can no longer benefit from the increase in productivity as a result of training and bears only its costs. Thus, investment in general human capital is only worthwhile for firms if the trainees are paid wages after completion of training which are lower than their productivity, and thus a margin can be realized. The new training literature discusses several reasons for this type of remuneration leading to a compressed wage structure in which, as skill increase, wages grow less quickly than productivity (Acemoglu / Pischke, 1998, 1999a, 1999b, Bassanini et al., 2005). In contrast to the human capital theory Acemoglu and Pischke discuss the case that because of the existence of mobility costs the individual's elasticity of labour supply with respect to an outside wage offer is less than infinity. Costs can be avoided as a result of lower staff turnover and if trainees remain for a relatively long period in the firm - with the additional advantage to save screening costs (Franz / Soskice, 1995). Therefore, the establishment's location is of importance, because the mobility costs and poaching differ according to the regional population density. The denser a region is in which the establishment is located, the higher is the probability that a trained employee leaves the training firm: "In Silicon Valley, a trained employee can just walk down the street and pick up a new and better paid job. If competitors are located far away, however, it takes a long walk to locate a better job, and some workers may be discouraged by the expected mobility costs." (Brunello / Gambarotto, 2007, 2). Mobility costs tend to decrease the establishments' willingness to finance further training the denser the establishment's location is.

On the other hand a denser local labour market can increase the establishment's benefits associated with further training and the incentive to finance these activities: Positive external effects may arise from regional "labour pooling" (Brunello / Gambarotto, 2007 and Brunello / De Paola, 2008). They argue that establishments which are located in the same region can exchange ideas and information and develop solutions to common problems. Regional economic studies demonstrate the positive effect of physical proximity on the diffusion of 
innovations and spillover of knowledge (Krugman, 1991). Especially the exchange of implicit knowledge depends on personal communications and networks, which are easier to develop and to sustain in geographic proximity. Regional density seems to be very relevant within the same industry. In this sense the advantages - identified by authors such as Marshall (1920), Arrow (1962) and Romer (1986) - which accrue to firms locating near other producers in the same industry is that geographic proximity helps spreading information and the exchange of ideas, the discussion of solution to problems and the awareness of other important information (Feldman, 1993). In this context further training is an important possibility for employees to participate in a mutual exchange of ideas. Within dense regions the organization of further training courses is easier not only because of the larger supply of training courses offered but also because training courses which are adopted to the needs of the employees are within a reasonable commuting distance between working and living place on the one hand and the location of the training centre on the other hand.

To summarize, it is not clear whether the relation between regional density and the employers' willingness to provide training for his employees is positive or negative: "When we compare similar firms in local labor markets with different density, this trade-off implies that (employer-provided) training incidence can be higher, or lower, in denser areas, depending on the relative weight of pooling and poaching effects." (Brunello / Gambarotto, 2007 , 2). Irrespective of this ambiguity the theoretical arguments presented justify the inclusion of regional variables in our multivariate analyses.

\section{Model Specification and Data Basis}

We analyze the impact of the regional context and firm characteristics on the probability to apply further training. As there are only two observable outcomes (application and nonapplication of training), the dependent variable is binary. For this reason, we estimate the application probability of further training using logit models. To account for the clustered and longitudinal structure of our data - with annual observations of firms and firms nested in regions - we apply a multi-level model (Rabe-Hesketh / Skrondal, 2008). Firm characteristics are available at the micro level, regional data are observed at the aggregate level. Multi-level models allow for grouping of establishments within regions and consider residuals at the establishment and the regional level. The residuals at the region level represent unobserved characteristics which lead to correlations between outcomes for establishments from the same region. Traditional regression analysis considers the observations as independent, however this assumption is violated and the standard errors will be underestimated. Therefore multi-level approaches are suitable for modeling cross-level interaction effects 
between variables located at different levels. For the empirical analysis we use a three-level logit random intercept model. This logit model for firm $i$ nested in region $j$ on occasion $t$ can be written as a generalized linear model with a link function:

$\eta_{i j t}=\beta_{0}+X_{i j t}^{\prime} \beta+u_{t i j}+\omega_{i j}+\gamma_{j}$, with $\mathrm{P}\left(\mathrm{Y}_{\mathrm{ijk}}=1\right)=\operatorname{logit}^{-1}\left(\eta_{i j t}\right)$

The variables $u_{t i j}, \omega_{i j}$ and $\gamma_{j}$ represent the random variables at the three dimensions, which follow a normal distribution with

$$
E\left(u_{t i j}\right)=E\left(\omega_{i j}\right)=E\left(\gamma_{j}\right)=0 \text { and } \operatorname{var}\left(u_{t i j}\right)=\sigma_{u}^{2}, \operatorname{var}\left(\omega_{i j}\right)=\sigma_{\omega}^{2}, \operatorname{var}\left(\gamma_{j}\right)=\sigma_{\gamma}^{2}
$$

The data basis for the estimation of the econometric model is the IAB Establishment Panel which is a general-purpose survey based on a random sample stratified by industries, establishment size, West and East Germany (Fischer et al., 2008). Each wave of the IAB Establishment Panel contains information well above 15,000 establishments. This paper uses data from four waves of the IAB Panel for the years 2001, 2003, 2005 and 2007, because questions about employer-provided further training are asked every second year. Since in the IAB Panel questions concern the most important determinants of employerprovided further training it is possible to study this issue with a dummy variable indicating the use of employer-provided further training at the establishment level.

To account for the employment structure we include both the proportion of qualified employees, those with fixed-term contracts and part-time employees into our analyses. For the proportion of qualified employees we expect a positive influence on further training, because qualified persons have shown that they are able to learn successfully, so that it can be assumed that they are especially interested to participate in training measures. For the both the proportion of persons with fixed-term contracts or in part-time work we expect negative effects, because the expected tenure or the employment volume are shorter or smaller respectively, so that the returns from human capital investments tend to be smaller as well.

Then, we investigate the effect of the industrial relations at the establishment level for the training provision. Since the German Works Constitution Act contains regulations concerning the codetermination and consultation rights of the works councils in the field of employerprovided further training we defined a respective dummy. Furthermore, we considered the effect of a dummy indicating whether or not the respective establishment is covered by a collective agreement negotiated at the firm or sector level, because some of these agreements include regulations about further training. 
Technological change incorporated in product and process innovations leads to further training, because they demand new competences and qualifications. In our multivariate analyses we control for the modernity of technical equipment (measured by means of a Likert scale) and dummies indicating product innovations as well as investments in IT and machinery. Positive business expectation and a large proportion of vacancies as well as the number of quits in relation to the total number of separations are connected with recruitments of personnel that may not be adequately qualified for the jobs to be filled. Therefore, the establishments have to provide further training to secure the adaptation of qualification and competences of their employees.

To capture the regional effects we consider the regional unemployment rate, the regional concentration of an industry (Andrews et al., 2009) ${ }^{1}$ and the regional population density ${ }^{2}$. Thereby, a new delineation of 150 German labour market regions is used (Eckey et al., 2006): The regions fulfil the criterion of reasonable commuting time (maximally 45 to 60 minutes in dependence of the attractiveness of the centre) and have a size of more than 50,000 inhabitants. Every region contains one or more administrative units. The unemployment rate, the population density as well as the concentration index is measured on the basis of these labour market regions. Following Brunello and DePaola (2008) and Brunello and Gambarotto (2007) the population density variable represents local economic density and agglomeration, whereas specialization is measured by the ratio of employment in the own industry and area and employment in the area.

Instead of using the logarithm of the population density we avoid the assumption of a functional form by introducing four dummy variables for low, medium, high and highest population densities.

${ }^{1}$ The region-sectoral concentration index is based on the 3-digit sector classification and the 150 labour market regions: $\sum_{i=1}^{N}\left(L_{i} / \sum L_{i}\right)^{2}$ with $L_{i}=$ number of employees in firm i (Gerner / Stegmaier, 2009). A low value (down to 0 ) can be interpreted as high sectoral competition within the labour market region whereas a high value (up to 1) means low competition.

${ }^{2}$ Population density: number of people per $\mathrm{km}^{2}$ (log.) 
The regional unemployment rate refers to the differences between regions with respect to the availability of qualified personal. The higher the regional unemployment the easier in terms of money and time qualified employees can be recruited (Niederalt, 2004).

Last but not least dummies for sector affiliation and the number of employees (measured in logs) as a proxy for establishment size are included in the multivariate analyses. Since we expect those establishments which belong to a larger firm show a similar training participation as the larger establishments we include a dummy indicating an independent establishment.

We use for the empirical analysis both a balanced and unbalanced panel data set to assess the validity of the empirical results. The descriptive statistics of the variables of the empirical model for East and West Germany are presented in Table 1. There are only slight differences in the prevalence of further training in the two parts of Germany. About 60 per cent of all firms in the sample (West: 64\%, East: 58\%) offer further training to at least one of their employees. However, the regional determinants show distinctive differences between

the two regions: The mean unemployment rate in East Germany is twice as high as in West Germany (West: 9\%, East: 18\%). The same is true for the population density: While West Germany is characterized by rather dense population agglomerations, parts of East Germany are sparsely populated and suffer migration towards the Western parts of Germany. The sample size of the balanced panel is 7596 for East Germany and 7536 for West Germany; the sample size of the unbalanced panel is 18388 for East and 27179 for West Germany.

\section{Empirical Results}

Table 2 displays the estimated coefficients and the standard errors of balanced and unbalanced random-effects models with three levels. In addition the results of standard random-effects panel logit models without consideration of different levels are presented. The likelihood ratio test shows that the three random effects, taken together, provide a substantially better fit than does standard logistic regression.

The coefficients of variables which account for the employment structure (i.e. the proportion of qualified employees, those with fixed-term contracts and part-time employees), industrial relations (i.a. collective agreements and works councils), technological change (product innovations, IT and machinery investment and modernity of technical equipment) and the firm size are highly significant and with theoretically expected signs. Within the group of variables referring to the adaptation of qualification and competences of the employees this is not always the case. For example the business expectations are significant in West 
Germany only, whereas the proportion of vacancies and the proportion of quits are never significant anyway.

The results for the regional indicators emphasize the necessity for applying multi-level models: The unemployment rate has a highly significant negative effect in the balanced and unbalanced models for West Germany only. However, the significantly positive effect for East Germany in the standard random effects model disappears when considering the different levels in the multi-level model.

The population density dummies initially reveal a nonlinear correlation in the RE panel logit models for East Germany. While the dummy "higher population density" is positively correlated to further training, the dummy "highest population density" is negatively correlated. However, the latter correlation disappears in the multi-level model. Therefore we only observe a positive correlation between East German regions with a "higher population density" and further training. In West Germany we do not observe any correlation between the population density and further training activities, neither in the Random effects models nor in the multi-level models.

The influence of the sector/regional concentration index is not significant in any of the regression models estimated. This result is in line with the study of Brunello / De Paola (2008) for Italy and Brunello / Gambarotto (2007) for the UK. In their analysis this regional specialization, measured by the ratio of employment in the own industry and area and employment in the area, does not seem to have any significant additional effect on training.

With respect to the population density variable the results of the multi-level models are in accordance with those obtained by Bellmann / Leber (2005) and support the pooling thesis. However, we only observe a positive correlation between East German regions with a "higher population density" and further training. The dummy "higher population density" represents first and foremost the regional economic cluster of Leipzig. Besides an intensive public promotion of the regional economy and the associated prevalence of numerous branches of multinational companies, the educational level of the employees and inhabitants is disproportional high. Moreover, the city has a considerable number of research institutes and universities (Heidenreich, 2005, 746).

\section{Summary and Conclusion}

In this paper we have studied the effects of the regional population density, the unemployment rate and the regional concentration of an industry against the background of several determinants of further training at the establishment level. From a methodological 
point of view multi-level approaches are adequate allowing the separation of the effects at the establishment and the regional level.

The unemployment rate has a highly significant negative effect for West Germany, only. In contrast a positive correlation between East German regions with a "higher population density" and further training is revealed. The influence of the sector/regional concentration index on further training is not significant in any of the models. Whereas, the results of the Random effects models are very similar in the case of the regional concentration of an industry, the effect partly disappears for the impact of the regional unemployment rate and the population density when applying the multi-level models. Our results corroborate the hypothesis that the regional unemployment refers to the differences between regions with respect of availability of qualified personal. The higher the regional unemployment the easier in terms of money and time qualified employees can be recruited. The results of the multilevel models for the population density dummies support the pooling thesis. However, evidence can only be found within the economic cluster of Leipzig.

Individuals, firms and institutional actors are embedded in regional political, social and economic structures that influence economic behaviour. Consequently, the regional context should be considered in empirical research strategies if data is available. The analysis at hand shows that regional particularities like the unemployment rate or the population density can influence training decisions of firms. Moreover, the variations in regional labour market conditions can be used as an identification strategy in papers on training choices (i.e. Parent, 2006). However, accounting for the regional and firm context simultaneously requires empirical methods that explicitly consider this multi-level character of economic structures. 


\section{References}

Acemoglu, D. I Pischke, J.-St. (1998), Why do firms train? Theory and evidence, Quarterly Journal of Economics 113, 79-119.

Acemoglu, D. / Pischke, J.-St. (1999a), Beyond Becker: Training in imperfect labour markets, The Economic Journal 109, F112-F142.

Acemoglu, D. / Pischke, J.-St. (1999b), The structure of wages and investment in general training, Journal of Political Economy 107, 539-572.

Andrews, M. / Bellmann, L. / Schank, T. / Upward, R. (2009), The takeover and selection effects of foreign-owned establishments: An analysis using linked employer-employee data, Review of World Economics 145, 293-317.

Arrow, K. J. (1962), Economic welfare and the allocation of resources for invention, in R. R. Nelson (ed.), The rate and direction of inventive activity, Princeton.

Bassanini, A. / Booth, A. / Brunello, G. / De Paola, M, / Leuven, E. (2005), Workplace training in Europe, IZA-Discussion Paper 1640.

Becker, G. S. (1964), Human Capital. A theoretical and empirical analysis, with special reference to education, New York / London.

Bellmann, L. / Leber, U. (2005), Betriebliche Weiterbildung im regionalen Kontext, Beiträge zur Arbeitsmarkt- und Berufsforschung 295, 107-122.

Brunello, G. / De Paola, M. (2008), Training and economic density: Some evidence form Italian provinces, Labour Economics 15, 118-140.

Brunello, G. I Gamberotto, F. (2007), Do spatial agglomeration and local labor market competition affect employer-provided training? Evidence from the UK, Regional Science and Urban Economics 37, 1-21.

Eckey, H.-F. I Türck, M. I Kosfeld R. (2006), Abgrenzung deutscher Arbeitsmarktregionen, Volkswirtschaftliche Diskussionsbeiträge 81.

Feldman, M. P. (1993), An examination of the geography of innovation, Industrial and Corporate Change 4, 451-470.

Fischer, G. I Janik, F. / Müller, D. I Schmucker, A. (2009), The IAB Establishment Panel. Things users should know, Schmollers Jahrbuch, Zeitschrift für Wirtschafts- und Sozialwissenschaften, 129, 133-148.

Franz, W. I Soskice, D. (1995), The German Apprenticeship System, F. Buttler / W. Franz I R. Schettkat / D. Soskice (eds.), Instititutional frameworks and labor market performance, London / New York, 208-234.

Gerner, H.-D. I Stegmaier, J. (2009), Unsicherheit und betriebliche Weiterbildung . Eine empirische Analyse der Weiterbildungsaktivität unter Unsicherheit in KMU und Großbetrieben, Zeitschrift für Betriebswirtschaft, Special Issue 6, 135-163.

Heidenreich, M. (2005), The renewal of regional capabilities: Experimental regionalism in Germany, Research Policy 34, 739-757.

Krugman, P. (1991), Geography and trade, Cambridge.

Marshall, A. (1920), Principles of economics, London.

Niederalt, M. (2004), Zur ökonomischen Analyse betrieblicher Lehrstellenangebote in der Bundesrepublik Deutschland, Frankfurt am Main.

Parent, D. (2006): Work while in high school in Canada: Its labour market and educational attainment effects, Canadian Journal of Economics 39, 1125-1150.

Rhabe-Hesketh, S. I Skrondal, A. (2008), Multilevel and longitudinal modeling using Stata, Texas.

Romer, P. (1986), Increasing returns and long-run growth, Journal of Political Economy 94, 1002-37. 


\section{Tables}

\begin{tabular}{|c|c|c|c|c|c|c|c|c|}
\hline \multirow[t]{2}{*}{ Balanced Panel } & \multicolumn{4}{|c|}{ East Gemany N=7596 } & \multicolumn{4}{|c|}{ West Germany N=7536 } \\
\hline & Mean & Std. Dev & Min & Max & Mean & Std. Dev & Min & Max \\
\hline Further training $(\mathrm{d})$ & 0,62 & 0,49 & 0 & 1 & 0,67 & 0,47 & 0 & 1 \\
\hline \% qualified employees & 0,72 & 0,25 & 0 & 1 & 0,64 & 0,26 & 0 & 1 \\
\hline$\%$ employees with fixed-term contracts & 0,05 & 0,13 & 0 & 1 & 0,04 & 0,08 & 0 & 1 \\
\hline$\%$ part-time employees & 0,15 & 0,22 & 0 & 1 & 0,21 & 0,23 & 0 & 1 \\
\hline Collective agreement (d) & 0,40 & 0,49 & 0 & 1 & 0,65 & 0,48 & 0 & 1 \\
\hline Works council $(\mathrm{d})$ & 0,30 & 0,46 & 0 & 1 & 0,46 & 0,50 & 0 & 1 \\
\hline Employment subsidies (d) & 0,34 & 0,47 & 0 & 1 & 0,26 & 0,44 & 0 & 1 \\
\hline Product innovations (d) & 0,43 & 0,49 & 0 & 1 & 0,51 & 0,50 & 0 & 1 \\
\hline Investment in IT (d) & 0,47 & 0,50 & 0 & 1 & 0,57 & 0,49 & 0 & 1,00 \\
\hline Machinery investment (d) & 0,49 & 0,50 & 0 & 1 & 0,54 & 0,50 & 0 & 1 \\
\hline $\begin{array}{l}\text { Modernity of technical equipment } \\
\text { (1=state of the art, } 5=\text { old })\end{array}$ & 2,21 & 0,74 & 1 & 5 & 2,18 & 0,76 & 1 & 5 \\
\hline $\begin{array}{l}\text { Business expectations } \\
\text { (-1:negative, } 0 \text { : constant },+1 \text { : positive) }\end{array}$ & $-0,04$ & 0,67 & -1 & 1 & 0,06 & 0,67 & -1 & 1 \\
\hline Proportion vacancies/total number of employees & 0,01 & 0,07 & 0 & 2 & 0,01 & 0,05 & 0 & 2 \\
\hline $\begin{array}{l}\text { Proportion of quits } \\
\text { (voluntary terminations)/total number of separations }\end{array}$ & 0,10 & 0,27 & 0 & 1 & 0,20 & 0,34 & 0 & 1 \\
\hline Independent establishment (d) & 0,81 & 0,39 & 0 & 1 & 0,70 & 0,46 & 0 & 1 \\
\hline Number of employees (log) & 3,06 & 1,60 & 0 & 8,08 & 3,66 & 1,83 & 0 & 9,90 \\
\hline Unemployment rate & 0,18 & 0,03 & 0,09 & 0,25 & 0,09 & 0,03 & 0,04 & 0,19 \\
\hline Low population density & 0,40 & 0,49 & 0 & 1 & 0,11 & 0,32 & 0 & 1 \\
\hline Medium population density & 0,37 & 0,48 & 0 & 1 & 0,43 & 0,50 & 0 & 1 \\
\hline Higher population density & 0,03 & 0,18 & 0 & 1 & 0,35 & 0,48 & 0 & 1 \\
\hline Highest population density & 0,16 & 0,37 & 0 & 1 & 0,10 & 0,30 & 0 & 1 \\
\hline $\begin{array}{l}\text { Sector/regional concentration index } \\
\text { (0: high competition, 1: high concentration) }\end{array}$ & 0,07 & 0,11 & 0,001 & 1 & 0,05 & 0,10 & 0,00 & 1 \\
\hline
\end{tabular}




\begin{tabular}{|c|c|c|c|c|c|c|c|c|}
\hline \multirow[t]{2}{*}{ Unbalanced Panel } & \multicolumn{4}{|c|}{ East Gemany N=18388 } & \multicolumn{4}{|c|}{ West Germany N=27179 } \\
\hline & Mean & Std. Dev & Min & Max & Mean & Std. Dev & Min & Max \\
\hline Further training $(d)$ & 0,59 & 0,49 & 0 & 1 & 0,64 & 0,48 & 0 & 1 \\
\hline$\%$ qualified employees & 0,70 & 0,27 & 0 & 1 & 0,62 & 0,28 & 0 & 1 \\
\hline \% employees with fixed-term contracts & 0,06 & 0,15 & 0 & 1 & 0,04 & 0,11 & 0 & 1 \\
\hline$\%$ part-time employees & 0,16 & 0,24 & 0 & 1 & 0,22 & 0,24 & 0 & 1 \\
\hline Collective agreement (d) & 0,39 & 0,49 & 0 & 1 & 0,58 & 0,49 & 0 & 1 \\
\hline Works council $(\mathrm{d})$ & 0,29 & 0,45 & 0 & 1 & 0,40 & 0,49 & 0 & 1 \\
\hline Employment subsidies (d) & 0,35 & 0,48 & 0 & 1 & 0,25 & 0,43 & 0 & 1 \\
\hline Product innovations (d) & 0,43 & 0,49 & 0 & 1 & 0,50 & 0,50 & 0 & 1 \\
\hline Investment in IT (d) & 0,46 & 0,50 & 0 & 1 & 0,55 & 0,50 & 0 & 1 \\
\hline Machinery investment (d) & 0,46 & 0,50 & 0 & 1 & 0,49 & 0,50 & 0 & 1 \\
\hline $\begin{array}{l}\text { Modernity of technical equipment } \\
(1=\text { state of the art, } 5=0 \text { old })\end{array}$ & 2,23 & 0,78 & 1 & 5 & 2,18 & 0,78 & 1 & 5 \\
\hline $\begin{array}{l}\text { Business expectations } \\
(-1: \text { negative, } 0: \text { constant },+1: \text { positive }) \\
\end{array}$ & $-0,03$ & 0,67 & -1 & 1 & 0,06 & 0,68 & -1 & 1 \\
\hline Proportion vacancies/total number of employees & 0,02 & 0,18 & 0 & 20 & 0,02 & 0,17 & 0 & 25 \\
\hline $\begin{array}{l}\text { Proportion of quits } \\
\text { (voluntary terminations)/total number of separations }\end{array}$ & 0,11 & 0,27 & 0 & 1 & 0,20 & 0,34 & 0 & 1 \\
\hline Independent establishment (d) & 0,79 & 0,41 & 0 & 1 & 0,70 & 0,46 & 0 & 1 \\
\hline Number of employees (log) & 2,96 & 1,66 & 0 & 9,56 & 3,38 & 1,84 & 0 & 10,8 \\
\hline Unemployment rate & 0,18 & 0,03 & 0,09 & 0,25 & 0,10 & 0,03 & 0,04 & 0,19 \\
\hline Low population density & 0,39 & 0,49 & 0 & 1 & 0,11 & 0,31 & 0 & 1 \\
\hline \multicolumn{9}{|l|}{ Medium population density } \\
\hline Higher population density & 0,03 & 0,18 & 0 & 1 & 0,38 & 0,48 & 0 & 1 \\
\hline Highest population density & 0,19 & 0,39 & 0 & 1 & 0,17 & 0,37 & 0 & 1 \\
\hline $\begin{array}{l}\text { Sector/regional concentration index } \\
\text { (0: high competition, } 1 \text { : high concentration) }\end{array}$ & 0,07 & 0,11 & 0,00 & 1 & 0,05 & 0,09 & 0,00 & 1 \\
\hline 2001 & 0,27 & 0,44 & 0 & 1 & 0,28 & 0,45 & 0 & 1 \\
\hline 2003 & 0,24 & 0,43 & 0 & 1 & 0,23 & 0,42 & 0 & 1 \\
\hline 2005 & 0,20 & 0,40 & 0 & 1 & 0,19 & 0,40 & 0 & 1 \\
\hline 2007 & 0,28 & 0,45 & 0 & 1 & 0,30 & 0,46 & 0 & 1 \\
\hline
\end{tabular}




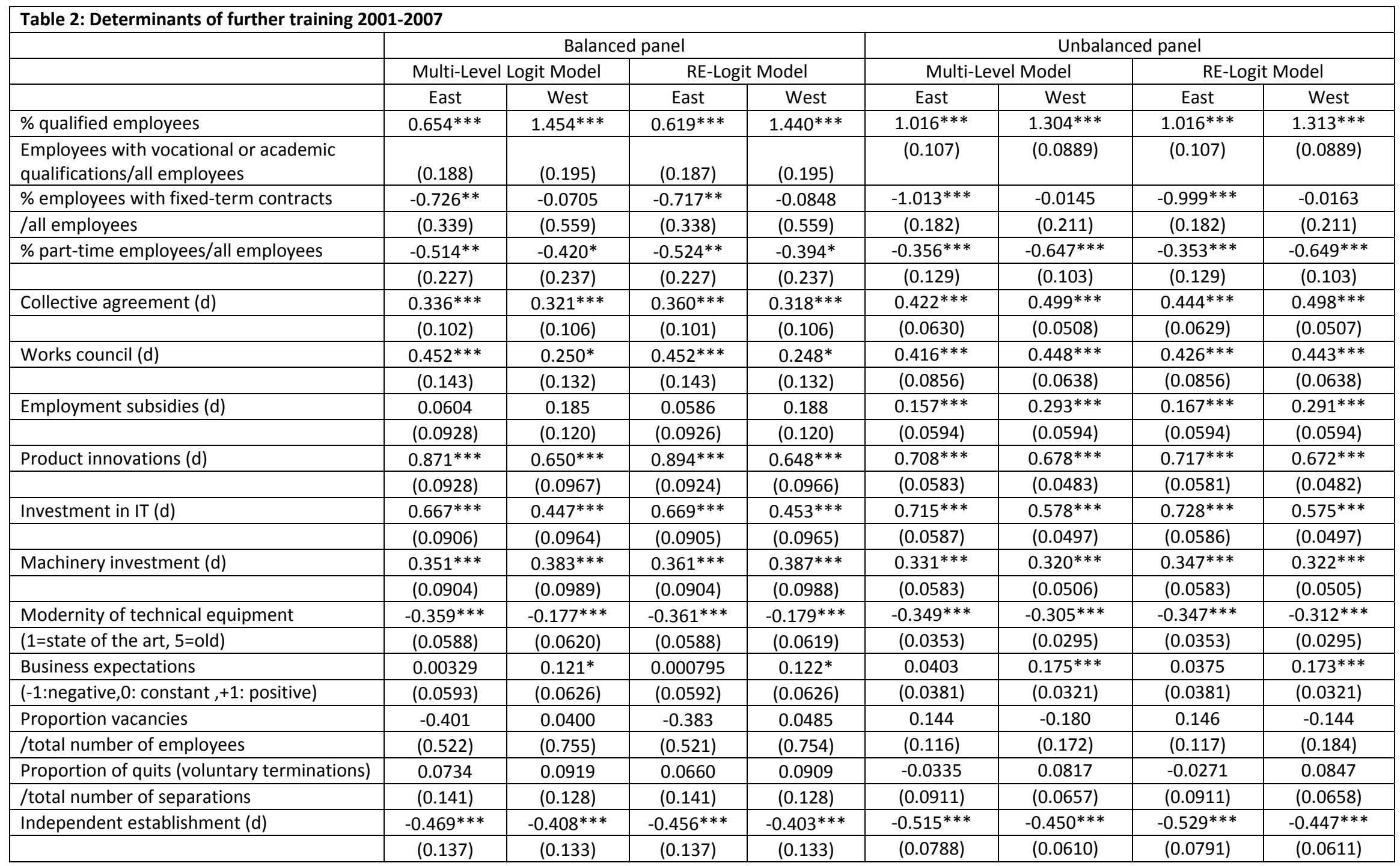




\begin{tabular}{|c|c|c|c|c|c|c|c|c|}
\hline \multirow[t]{2}{*}{ Number of employees (log) } & $0.645 * * *$ & $0.873 * * *$ & $0.643 * * *$ & $0.876 * * *$ & $0.662 * * *$ & $0.727^{* * *}$ & $0.652 * * *$ & $0.728 * * *$ \\
\hline & $(0.0527)$ & $(0.0574)$ & $(0.0526)$ & $(0.0575)$ & $(0.0299)$ & $(0.0251)$ & $(0.0298)$ & $(0.0251)$ \\
\hline \multicolumn{9}{|c|}{ Table 2: Determinants of further training 2001-2007 (continued) } \\
\hline & \multicolumn{2}{|c|}{ Multi-Level Logit Model } & \multicolumn{2}{|c|}{ RE-Logit Model } & \multicolumn{2}{|c|}{ Multi-Level Model } & \multicolumn{2}{|c|}{ RE-Logit Model } \\
\hline & East & West & East & West & East & West & East & West \\
\hline Sectors (d) & $* * *$ & $* * *$ & $* * *$ & $* * *$ & $* * *$ & $* * *$ & $* * *$ & $* * *$ \\
\hline \multicolumn{9}{|l|}{ Regional indicators } \\
\hline \multirow[t]{2}{*}{ Unemployment rate } & 3.494 & $-6.088 * *$ & $3.875^{* *}$ & $-6.163^{* *}$ & 2.250 & $-5.400 * *$ & 2.657 & $-5.636 * *$ \\
\hline & $(2.486)$ & $(2.957)$ & $(1.728)$ & $(2.502)$ & $(2.265)$ & $(2.715)$ & $(1.633)$ & $(2.215)$ \\
\hline Low population density & -0.199 & -0.148 & -0.124 & -0.139 & -0.171 & -0.0711 & -0.130 & -0.0736 \\
\hline Reference: Medium Population Density & $(0.147)$ & (0.198) & $(0.108)$ & $(0.186)$ & $(0.134)$ & $(0.179)$ & $(0.102)$ & $(0.163)$ \\
\hline Higher population density & $1.182 * *$ & -0.117 & $1.254 * * *$ & -0.0889 & $1.192^{* * *}$ & -0.0569 & $1.235^{* * *}$ & -0.0542 \\
\hline Reference: Medium Population Density & $(0.524)$ & $(0.154)$ & $(0.331)$ & $(0.129)$ & $(0.460)$ & $(0.147)$ & $(0.294)$ & $(0.116)$ \\
\hline Highest population density & -0.382 & 0.268 & $-0.308 * *$ & 0.181 & -0.360 & 0.230 & $-0.310 * *$ & 0.148 \\
\hline Reference: Medium Population Density & $(0.435)$ & (0.253) & $(0.155)$ & $(0.212)$ & $(0.381)$ & $(0.242)$ & $(0.145)$ & $(0.195)$ \\
\hline Sector/regional concentration index ${ }^{*}$ & -0.110 & 0.0489 & -0.0560 & 0.0540 & 0.00683 & -0.198 & 0.0595 & -0.188 \\
\hline (0: high competition, 1 : high concentration) & $(0.354)$ & $(0.428)$ & $(0.344)$ & $(0.424)$ & $(0.336)$ & $(0.397)$ & $(0.327)$ & $(0.393)$ \\
\hline \multirow[t]{2}{*}{2003} & $0.413 * * *$ & $0.214 * *$ & $0.412 * * *$ & $0.208^{*}$ & $0.455^{* * *}$ & $0.326^{* * *}$ & $0.464^{* * *}$ & $0.306 * * *$ \\
\hline & $(0.0969)$ & $(0.106)$ & $(0.0966)$ & $(0.106)$ & $(0.0647)$ & $(0.0589)$ & $(0.0645)$ & $(0.0580)$ \\
\hline \multirow[t]{2}{*}{2005} & $0.235^{* *}$ & $0.327 * * *$ & $0.236 * *$ & $0.321^{* * *}$ & $0.454 * * *$ & $0.447 * * *$ & $0.457 * * *$ & $0.433 * * *$ \\
\hline & $(0.0981)$ & $(0.109)$ & $(0.0979)$ & $(0.109)$ & $(0.0692)$ & $(0.0627)$ & $(0.0692)$ & $(0.0620)$ \\
\hline \multirow[t]{2}{*}{2007} & $0.583 * * *$ & 0.166 & $0.585^{* * *}$ & 0.161 & $0.581 * * *$ & $0.356 * * *$ & $0.589 * * *$ & $0.338 * * *$ \\
\hline & $(0.100)$ & $(0.108)$ & $(0.0999)$ & $(0.108)$ & $(0.0654)$ & $(0.0572)$ & $(0.0653)$ & $(0.0565)$ \\
\hline \multirow[t]{2}{*}{ Constant } & $-1.512 * * *$ & $-2.503 * * *$ & $-1.640 * * *$ & $-2.490 * * *$ & $-1.617^{* * *}$ & $-2.281 * * *$ & $-1.688 * * *$ & $-2.350 * * *$ \\
\hline & $(0.541)$ & $(0.404)$ & $(0.428)$ & $(0.378)$ & $(0.450)$ & $(0.200)$ & $(0.251)$ & $(0.169)$ \\
\hline Observations & 7596 & 7536 & 7596 & 7536 & 18388 & 27179 & 18388 & 27179 \\
\hline Number of groups (idnum) & 1916 & 1910 & 1899 & 1884 & 2239 & 3039 & 8703 & 14801 \\
\hline Number of groups (ram) & 42 & 107 & & & 42 & 112 & & \\
\hline \multicolumn{9}{|l|}{ LR-Test versus logistic regression: } \\
\hline chibar2(02) & 494.21 & 458.46 & & & 806.92 & 811.00 & & \\
\hline Prob>chi2 & 0.0000 & 0.0000 & & & 0.0000 & 0.0000 & & \\
\hline
\end{tabular}


